\title{
Population size, group and age structure of geladas (Theropithecus gelada) in escarpments of Eastern Tigray, Ethiopia: implication for conservation
}

\author{
Teklay Girmay * (D) and Deribe Dati
}

\begin{abstract}
Background: Geladas (Theropithecus gelada), endemic to Ethiopia, are distributed closely related to the escarpments and gorge systems of the country, and large populations are found in the Simien Mountain National Park. This study was conducted in Eastern Tigray, Northern Ethiopia, from February 2018 to August 2019 in order to determine population size and composition of geladas. Total count method was used to estimate the population structure of geladas. Observations of the group of geladas based on body size and morphological characteristics were used to classify age and sex categories of the population. SPSS Version 20 was used to analyze the data. Chisquare test was used to compare sex ratio of geladas and population size among the counting sites between wet and dry seasons.
\end{abstract}

Results: A total of 112 and 99 individual of geladas were counted during wet and dry seasons, respectively. Of the average gelada population recorded in this study, $11.4 \%$ were adult males, $30.3 \%$ were adult females, $12.8 \%$ were sub-adult males, $25.6 \%$ were sub-adult females, and $19.9 \%$ were unidentified juveniles. However, there was no statistically significant difference among the various age and sex groups of geladas counted during wet and dry season $\left(X^{2}=2.6, D F=4, P>0.05\right)$. Variations of group size along seasons were observed in this study. Sex ratio of adult male to adult female was 1:2.6 and 1:2.7 during the dry and wet seasons, respectively.

Conclusion: Very small gelada population size was recorded in the current study. An average of 105.5 geladas was recorded during the study period. As this is the first report of gelada population in escarpments of Eastern Tigray, population trend of the geladas cannot decide based on the current study.

Keywords: Age structure, Eastern Tigray, Geladas, Population size, Total count

\section{Background}

Gelada (Theropithecus gelada) is a primate species endemic to Ethiopia, and most of its distribution is closely related to the escarpments and gorge systems of the country (Yalden and Largen 1992). Geladas are primate animals that are the only extant species of genus Theropithecus. Both male and female geladas possess a triangular bare red skin on their chest and a crescent-

\footnotetext{
* Correspondence: tekigir9@gmail.com

Department of Biology, Adigrat University, P. O. Box, 50 Adigrat, Ethiopia
}

shaped one on their throat. This makes them distinguished from Papio spp morphologically (Ankel-Simons 2007). They are also distinguished from Papio spp in the presence of the shorter jaws, longer face, a bulging cheek, and a snub snout which is similar to the snout of chimpanzee (Radek et al. 2014). Geladas live in complex multi-leveled social groups. A social group consists of a leader male, several adult females, and their offspring are the one-male units (OMUs). Another group structure of geladas composed of 2-15 males is called the bachelor all-male units (AMUs) (Gippoliti and Hunter 2008).

(c) The Author(s). 2020 Open Access This article is licensed under a Creative Commons Attribution 4.0 International License, which permits use, sharing, adaptation, distribution and reproduction in any medium or format, as long as you give appropriate credit to the original author(s) and the source, provide a link to the Creative Commons licence, and indicate if changes were made. The images or other third party material in this article are included in the article's Creative Commons licence, unless indicated otherwise in a credit line to the material. If material is not included in the article's Creative Commons licence and your intended use is not permitted by statutory regulation or exceeds the permitted use, you will need to obtain permission directly from the copyright holder. To view a copy of this licence, visit http://creativecommons.org/licenses/by/4.0/ 
OMUs and AMUs that share a common home range are called a band that contains 30 to 260 geladas (Dunbar and Dunbar 1975). Even though geladas were evaluated as least concern in the IUCN Red List of Threatened Species, the current population is decreasing due to a restricted extent of occurrence and major threats such as habitat loss, human population growth, agricultural expansion, and hunting in response to crop raiding (Gippoliti and Hunter 2008).

The genus Theropithecus had a wider geographical distribution throughout the savannah grasslands of subSaharan Africa during the late Miocene and early Pliocene (Jablonski 1993). However, it is currently restricted to some parts of northern and southern highlands of Ethiopia. Earth's climate in the montane grassland zones of sub-Saharan Africa may have resulted in the extinction of all the populations of the Theropithecus throughout their range in eastern and southern Africa outside the Ethiopian central highlands (Dunbar 1998). It is also believed that a combination of various factors such as predation, climate change, and inter specific competition with ungulates might have contributed to their extinction (Kingdon 1997).Today, geladas are found in few areas of the Northern Ethiopian Highlands. Studies indicated that the highest density of geladas, and the only place where they are officially protected, occurs is in the Simien Mountains National Park (Beehner et al. 2008) and small populations of gelada occurs in Guassa (Fashing et al. 2014), Wollo (Gippoliti 2010), DebreLibanos (Kassahun et al. 2017; Kassahun and Afework 2017), Wof-Washa Forest in North Shewa Zone (Birhanu and Mesele 2018), and in the south of the Rift Valley Arsi Province (Mori and Belay 1990).

Although few studies reported the occurrence of geladas in Tigray region historically (Yalden and Largen 1992; Gippoliti 2010), no research has been conducted on the population status, group, and age structure of the species. Hence, the current study intended to study the population size, social group, and age structure of Theropithecus gelada in Tigray region, Ethiopia. Accurate population estimates of endemic animals across time will determine whether numbers of a particular species are being maintained, in decline, or in recovery. Further, establishing accurate numbers for each species is a critical first step for conservation and management policies (Beehner et al. 2008). Accordingly, population size, group composition, and age structure of geladas that found in other parts of Ethiopia have been studied in different times by different scholars (Habtamu and Subramanian 2013; Zewdu et al. 2013; Kassahun and Afework 2017; Dessalegn and Afework 2017; Beehner et al. 2008; Birhanu and Mesele 2018). However, study on the population size, group, and age structure of geladas in Tigray in general in the current study area in particular is surprisingly limited. Thus, the aim of this study was to investigate population size, group, and age structure of geladas in escarpments of Eastern Tigray, Ethiopia.

\section{Methods}

\section{Study area}

The study was conducted in escarpments of Eastern Tigray, Northern Ethiopia. The escarpments are found in border of Hawzien and Ganta-Afeshum administrative districts having altitudes ranging between 2623 and 2654 m.a.s.l. The study sites include Debre-Abay and Debre-Mizen (14 $\left.08^{\prime} 17^{\prime \prime} \mathrm{N}-39^{\circ} 25^{\prime} 48^{\prime \prime} \mathrm{E}\right)$ from Hawzien Woreda, and Hadnet (14. 09' $54^{\prime \prime}$ ' N-39 $24^{\circ}$ $01^{\prime \prime}$ E) from Ganta-Afeshum Woreda and is the only location for habitat of geladas in Tigray Region (Fig. 1). The area is currently covered by a variety of flora and fauna. The study site is found about $22 \mathrm{~km}$ North of Hawzien and about $16 \mathrm{~km}$ South of Adigrat. Hawzien is located at $60 \mathrm{~km}$ South West of Adigrat and about 110 $\mathrm{km}$ far away from the capital city of Tigray, Mekelle.

The study area consists of various wild mammals including spotted hyena (Crocuta crocuta), rock hyrax (Procavia capensis), common jackal (Canis aureus), civet (Civettictis civetta), striped ground squirrel (Xerus erythropus), leopard (Panthera pardus), monkeys (Cercopithecus aethiops), porcupine (Hystrix spp.), numerous bird species such as sunbirds (Cinnyris spp), blue capped cordon bleu (Uraeginthus cyanocephalus), lammergeyers (Gypaetus barbatus), and batteleur eagles (Terathopius ecaudatus). Moreover, the study area includes various vegetations such as Acacia etbaica, Carissa spinarum, Croton macrostachyus, Dodonea angustifolia, Euclea racemosa, Eucalyptus citriodora, Euphorbia candelabrum, Olea europaea, Euphorbia tirucalli, Ekebergia capensis, and Ficus vasta (Teklay and Zeyede 2017).

The average precipitation of the study areas is $600 \mathrm{~mm}$ with $313 \mathrm{~mm}$ and $770 \mathrm{~mm}$ minimum and maximum annual rainfall, respectively. The rainy season of the study area is from June up to September and the dry season is from January to May, and it receives a minimum and maximum rainfall in April and July, respectively. The maximum and minimum temperature of the study area is $24{ }^{\circ} \mathrm{C}$ and $6.9^{\circ} \mathrm{C}$, respectively (Gebrehiwot and van der Veen 2013).

\section{Data collection}

Preliminary survey was conducted in the study area during January 2018. During this period, we collected information such as vegetation, fauna, topography, and occupancy of geladas in the area. Further, the method of data collection was prepared. Based on the preliminary surveys, the study areas are identified and counting 


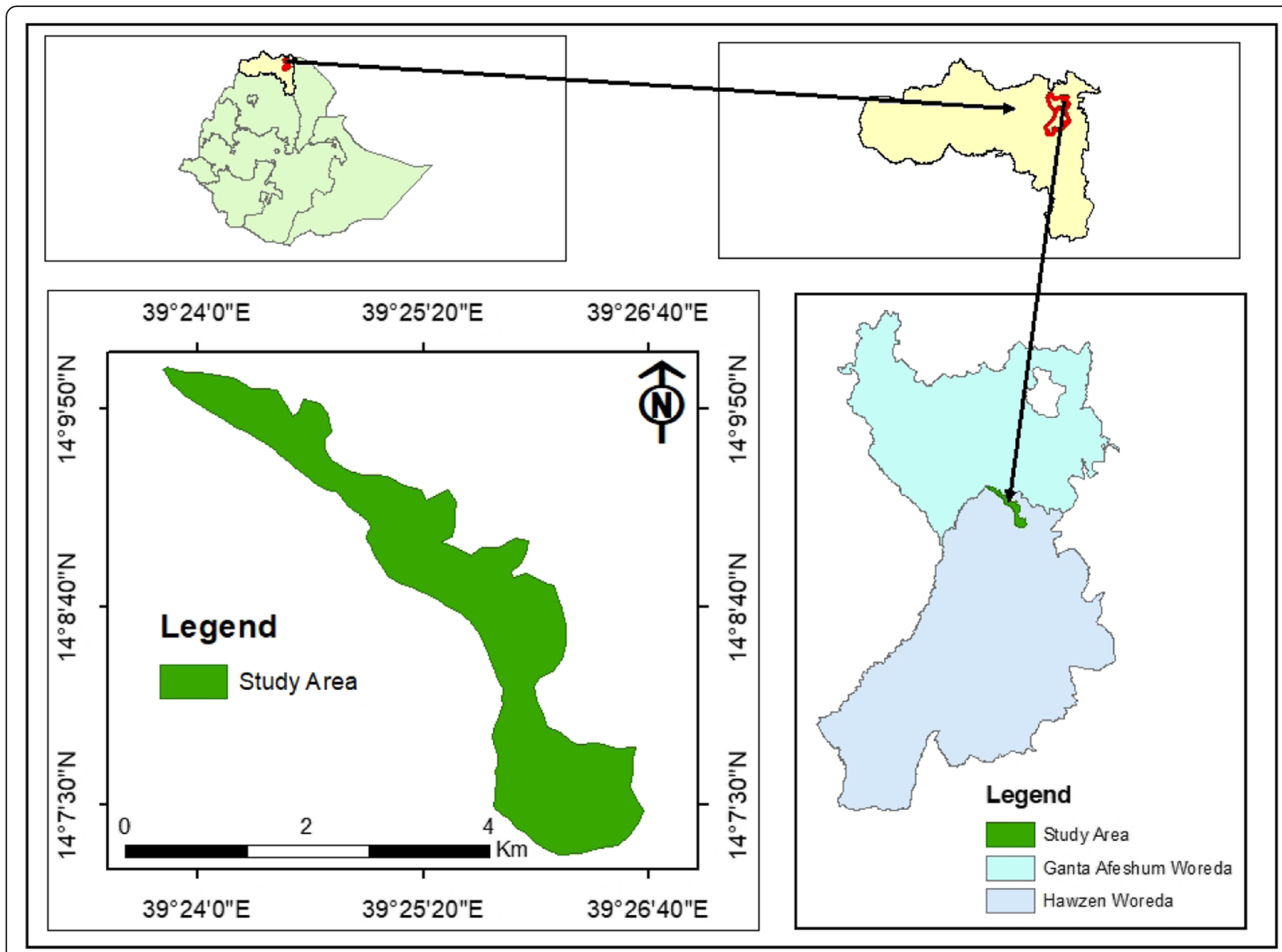

Fig. 1 Location of the study area (upper left: Ethiopia, upper right: Tigray region, lower right: Hawzen and Ganta-Afeshum woreda, and lower left: study area)

blocks are classified based on natural boundaries such as small hills and mountains.

Actual data was collected from February 2018 to August 2019 to cover both the wet and dry seasons. During field survey, we recorded population size, group, and age structure of gelada. Due to isolated of study sites and rare population of geladas in Eastern Tigray, direct total count method was adopted to estimate the population size of geladas at the study site (Sutherland 1996). Total count method is the most effective method for determining population estimates for medium to largesized animals that live in open habitat where visibility and monitoring will be easy (Norton-Griffths 1978; Sutherland 1996; Beehner et al. 2008). These characteristics hold true for geladas in the current study area. Further, in the early morning, geladas are found along cliff edges for sun basking and feeding, where observers can find all individuals in a given area. We determined the group type of the population. Animals were considered as the same group if the distance between them was less than $50 \mathrm{~m}$ (Oates 1977; Sicotte and Macintosh 2004). To determine the group structure, once gelada monkey group was spotted, they were categorized based on social organization and classified into OMUs, AMUs, and bands (Zewdu et al. 2013).

Observations of the troop of geladas were used to classify individuals as adult males, adult females, sub-adult males, sub-adult females, and juveniles based on their body size and morphological characteristics. Adult males were defined as males with manes and size about twice that of the adult females. Sub-adult males were males similar in size to adult females and with initial development of manes. Adult and sub-adult females were identified based on the body size. All other individuals were considered as juveniles based on the body size. Furthermore, identification of sex and age categories was made using genitalia and red patches of the skin on their chest and anogenital regions, bulges on the buttock, and pelage color (Dunbar and Dunbar 1975; Mori et al. 1999; Beehner et al. 2008) (Table 1).

All gelada counts were conducted simultaneously on the same day during morning hours to avoid double 
Table 1 General body size and morphological characteristics describing age-sex category of geladas (Dunbar and Dunbar 1975; Mori et al. 1999; Beehner et al. 2008)

\begin{tabular}{ll}
\hline Age-sex category & Characteristics \\
\hline Adult male & Larger in size and about twice that of the adult females, thick golden hairy cape receded back to shoulders, \\
& hair dull in color and uneven in places, the cheek tufts receded back to chin line, the ears somewhat visible \\
& to highly visible, hairless hourglass-shaped red area of the skin located on the chest is bright red and \\
& surrounded by white hair \\
& Smaller than the adult males, lack cape, more uniform in pelage color, hairless hourglass-shaped red area of \\
the skin located on the chest is surrounded by pearl-like knobs of skin, the skin of the neck and chest pale \\
pink surrounded by vesicles that swell to indicate periovulatory period, vesicles present on the inner thighs \\
and paracallosal skin
\end{tabular}

counting (Beehner et al. 2008). Field binocular was used for counting animals at distance (above $50 \mathrm{~m}$ ) and for identification of age and sex. The steep cliffs and overall topographic features of the study area are difficult to conduct transect count method. Census of geladas' population was made by classifying the study site into three different sized blocks for the purpose of direct counting based on the suitability of the area for walking on foot and visibility of the animals. Division of the study area was based on natural boundaries such as small hills and mountains. Censuses were conducted on foot by the researchers and together with residents who are familiar with the area.

\section{Data analysis}

SPSS software for Windows Evaluation Version 20 was used to run the analysis. Statistical tests used were twotailed with 95\% confidence intervals. Chi-square test was used to compare the statistical differences between the sex ratio of gelada and population size among the counting sites between wet and dry seasons.

\section{Results \\ Population size}

The total counts of gelada individuals in the study area for both wet and dry seasons were 112 and 99, respectively. The average number of geladas during the study period was 105.5 . The population size in the study area was significantly higher during the wet season than the dry season $\left(x^{2}=6.78, \mathrm{DF}=2, P<0.05\right)$. Geladas were observed during the two seasons in the three study sites. The highest numbers of geladas $61.1 \%$ and $49.1 \%$ were recorded in the Erar site during dry and wet seasons, respectively (Table 2).

\section{Population composition}

Of the total population of geladas recorded during the dry season, $13.1 \%$ were adult males, $34.3 \%$ adult females, $12.1 \%$ sub-adult males, $22.2 \%$ sub-adult females, and
$18.1 \%$ an unidentified juvenile. During the wet season, 9.8\% were adult males, $26.8 \%$ adult females, $13.4 \%$ subadult males, $28.6 \%$ sub-adult females, and $21.4 \%$ an unidentified juvenile. There was no significant difference between the number of adult males and adult females $\left(\chi^{2}=0.008, \mathrm{DF}=1, P>0.05\right)$, sub-adult males and subadult females $\left(\chi^{2}=0.101, \mathrm{DF}=1, P>0.05\right)$, adult females and juveniles $\left(\chi^{2}=1.070, \mathrm{DF}=1, P>0.05\right)$ during dry and wet seasons. There was no statistically significant difference among the various age and sex groups of geladas counted during wet and dry season $\left(\chi^{2}=2.6, \mathrm{DF}=4, P>0.05\right)$.

\section{Group structure}

During the study period, a total of 3 bands and 2 OMUs of geladas were recorded during the dry season. Moreover, 4 bands and 1 OMU were observed during the wet season and no AMG was recorded during both seasons (Table 3). There was no significant difference between the total number of groups during the wet and dry seasons $\left(\chi^{2}=0.476, \mathrm{DF}=1, P>0.05\right)$. During the wet season, only one OMU was recorded with 28 group size. The maximum and minimum overall group size of band during wet and dry seasons was 37 and 31, respectively (Table 3). There was significance difference between the mean OMU size during the two seasons $\left(\chi^{2}=13.4\right.$, DF $=$ $1, P<0.05)$, but there was no significance difference between the mean band size during the wet season and dry seasons $\left(\chi^{2}=0.004, \mathrm{DF}=1, P>0.05\right)$.

Table 2 Number of geladas observed during dry and wet seasons from February 2018 to August 2019 at escarpments of Eastern Tigray

\begin{tabular}{lllll}
\hline Seasons & \multicolumn{2}{l}{ Study sites } & & Total \\
\cline { 2 - 4 } & Adi Asfeha & Erar & Degat & \\
\hline Dry & 17 & 55 & 27 & 99 \\
Wet & 36 & 55 & 21 & 112 \\
Mean & 26.5 & 55 & 24 & 105.5 \\
\hline
\end{tabular}


Table 3 Group type and size of geladas during the wet and dry seasons at the study sites from February 2018 to August 2019 in escarpments of Eastern Tigray

\begin{tabular}{|c|c|c|c|c|c|c|}
\hline \multirow{2}{*}{$\begin{array}{l}\text { Group } \\
\text { type }\end{array}$} & \multirow[t]{2}{*}{ Season } & \multicolumn{2}{|c|}{ Group size } & \multirow{2}{*}{$\begin{array}{l}\text { Mean } \\
\text { group } \\
\text { size }\end{array}$} & \multirow{2}{*}{$\begin{array}{l}\text { Number } \\
\text { of group }\end{array}$} & \multirow[t]{2}{*}{ Study sites } \\
\hline & & Max. & Min. & & & \\
\hline \multirow[t]{3}{*}{$\mathrm{OMU}$} & Wet & 28 & - & 28 & 1 & Adi Asfeha \\
\hline & Dry & 21 & 16 & 18.5 & 2 & Erar \\
\hline & Overall & 28 & - & 21.66 & 3 & \\
\hline \multirow[t]{3}{*}{ Band } & Wet & 37 & 32 & 32.25 & 4 & Adi Asfeha (2) and Degat (2) \\
\hline & Dry & 35 & 31 & 32 & 3 & Erar \\
\hline & Overall & 37 & 31 & 32.14 & 7 & \\
\hline
\end{tabular}

The sex ratio of adult male to adult female was 1.00: 2.6 during the dry season and 1.00:2.7 during the wet season. The age and sex ratio of adult male to adult female and sub-adult male to sub-adult female were the highest during the wet and dry seasons, respectively, with the ratio of 1.00:2.7 in the study area (Table 4).

\section{Discussion}

According to our observation from Febrarury2018 to August 2019, the total number of individual geladas counted in the study area was 112 and 99 during the wet and dry seasons, respectively. This shows that there was a difference in the total number of geladas counted during wet and dry seasons. Population size of the geladas during wet season was higher than the dry season. The gap of gelada population between the dry and wet seasons in the current study area might be caused by human disturbances. Human-gelada conflict leads to migration of the populations to adjacent areas to get better feeding site and reduce the effect of food scarcity (Kassahun and Afework 2017). The average population size of geladas (105.5) recorded in the current study area was less than the population size counted in Wof-Washa Forest Central Ethiopia with 453 individuals (Birhanu and Mesele 2018) and around the Simien Mountains National Park with 4264 geladas (Beehner et al. 2008). Similarly, an average of 1525 and 1607.5 individual geladas were recorded in Wonchit vally (Zewdu et al. 2013) and Debre-Libanos Northwest Shewa Zone (Kassahun \& Afework 2017), respectively. This indicated that the number of geladas found in the current study area was very few in number. This may be due to the intense

Table 4 Age and sex ratio of geladas during dry and wet seasons from February 2018 to August 2019 at escarpments of Eastern Tigray

\begin{tabular}{llllll}
\hline Seasons & \multicolumn{5}{l}{ Age and sex ratio } \\
\cline { 2 - 6 } & AM:AF & SAM:SAF & M:F & SAM:AM & SAF:AF \\
\hline Dry & $1.00: 2.6$ & $1.00: 2.7$ & $1.00: 2.24$ & $1.00: 1.08$ & $1.00: 1.54$ \\
Wet & $1.00: 2.7$ & $1.00: 1.8$ & $1.00: 2.38$ & $1.36: 1.00$ & $1.06: 1.00$ \\
\hline
\end{tabular}

human gelada conflict in the study area. In the study area the geladas live in close proximity to human settlement areas and raided farmers' crop starting from sowing till harvesting. The local people living around the study area chase geladas away from their nearby farmlands of the escarpment to other area and tried to kill geladas in order to reduce crop damage (Researchers' observation). This might be also due to severe droughts and many years of war in Tigray region. Unlike other gelada populations elsewhere in Ethiopia, the population in Tigray has lost its natural habitat through decades of land use/cover change (Zinner et al. 2018). Global warming and genetic loss may pose additional threats of the geladas in the current study area. Lack of access of water to geladas was observed during the dry season in the current habitat of geladas. Dunbar (1998) pointed out that global warming related with shortage of water and shortage of food during dry season is a risk factor for decrease of geladas. Highest numbers of geladas were recorded in Erar site during both dry and wet seasons. This might be due to the stability of the area than the other two sites. The two study sites called Adi Asfeha and Degat were used for human settlements, agricultural, and livestock rearing purposes. The distribution of animal population is based on the food availability, food quality, and distance from human (Wallace 2006).

In the population of geladas in this study, unequal age and sex composition were observed. Age and sex composition of geladas was dominated by adult females during dry season and sub-adult females during wet season. This unequal age and sex composition is consistent with the result that is observed in other studies (Birhanu and Mesele 2018; Zewdu et al. 2013). The possible reasons for an unequal sex ratio may be due to an increased predation pressure on males and the emigration of subordinate males to less favorable habitats (Zewdu et al. 2013). Different group sizes were observed in the current study area. This difference in group size of geladas may relate with human disturbance. The local community effects to a group size of geladas due to a conflict in response to crop raiding. With high conflict, 
the geladas may split into smaller groups to escape from their enemy. Different group size of geladas is also associated with food availability and environmental conditions. Band size is related with availability of food. Gelada band size may split into sub-units when available food resources are low in a degraded habitat (Iwamoto and Dunbar 1983). A study conducted in Indetu confirmed that gelada unit and band size decreased due to harsh climate and limited resources in the areas (Kelil et al. 2018).

The ratio of adult males to adult females of geladas was 1:2.6 and 1:2.7 in dry and wet seasons, respectively. The ratio of sub-adult males to sub-adult females was 1 : 2.7 during the dry season and 1:1.8 during wet season. This ratio was smaller than that was found by Birhanu and Mesele (2018) in Wof-Washa Forest (Gosh-Meda Area), Central Ethiopia, with the ratio of 1:6.1 and 1:6.3 adult males to adult females in wet and dry seasons, respectively. On the other hand, the current age and sex ratio was almost similar with that was found by Habtamu and Subramanian (2013) in the Simien Mountains National Park. The rate at which population may grow is dependent on the sex ratio in a population. The fewer the ratio of females in a population, the slower the rate of population growth. The number of females is usually directly related to the expected number of births.

\section{Conclusion}

The current study provided relevant information on population size, group, and age structure of geladas in escarpments of Eastern Tigray. The estimated population size of geladas in the current study was significantly lower than the previous studies in other localities of Ethiopia. The average number of geladas during the study period was 105.5. Population size recorded in the study area had significant difference during the wet and dry seasons. Unequal sex and age composition among the individual geladas was observed. It is difficult to conclude the population status of the geladas in the current study as the gelada populations have never been estimated previously. As the gelada population size recorded in the study area was small in number, conservation area should be developed for conservation of the species in their natural habitat.

\section{Abbreviations \\ OMU: One-male unit; AMG: All male group; AM: Adult male; AF: Adult female; SAM: Sub-adult male; SAF: Sub-adult female; M: Male; F: Female; Max.: Maximum; Min.: Minimum; m.a.s.I.: Meters above sea level}

\section{Acknowledgements}

We would like to thank Adigrat University for its financial support. The authors also owe great thanks to the Biology Department for provision of field materials. Many thanks go to the local community living in and around the study area for their cooperation in providing essential information for this research work
Ethics approval and consent to approval

Not applicable

\section{Authors' contributions}

The corresponding author TG had taken responsibilities of proposal drafting, data collection, and writing up the manuscript. The second author DD participated in data collection and commenting on the proposal and manuscript. Both authors read and approved the final manuscript.

\section{Funding}

Adigrat University provided fund for data collection with registration number AGU/CNCS/010/11.

\section{Availability of data and materials}

The data that supported the results of this research will remain intact with corresponding author. These data can be made available to anyone from the corresponding author on request.

\section{Consent for publication}

Not applicable

\section{Competing interests}

The authors declare that they have no competing interests.

Received: 27 September 2019 Accepted: 4 August 2020

Published online: 18 August 2020

\section{References}

Ankel-Simons F. Primate anatomy: an introduction, 3rd. San Diego: Elsevier Acad Pr. 2007; P.724.

Beehner JC, Berhanu G, Bergman TJ, Cann MC. Population estimate for gelada (Theropithecus gelada) living in and around the Simien Mountains National Park. Ethiopia. Ethiop J Scie. 2008;3:1-5.

Birhanu G, Mesele Y. Population structure and habitat use of gelada baboon (Theropithecus gelada) in Wof-Washa Forest (Gosh-Meda Area), Central Ethiopia. Journal of Ecology and Environment. 2018;42(3):1-6.

Dessalegn E, Afework B. Population structure and group size of geladas (Theropithecus gelada) at Chenek, Simien Mountains National Park, Ethiopia. Afr J Ecol. 2017:55:1-10

Dunbar RIM. Impact of global warming on the distribution and survival of the gelada baboon: a modeling approach. Glob Change Biol. 1998;4:293-304.

Dunbar RIM, Dunbar P. Social dynamics of gelada baboons. In: Kuhn H, Luckett WP, Noback CR, Schultz AH, Starck D, Szalay FS, editors. Contributions to primatology. Basel: Karger S; 1975.

Fashing PJ, Nguyen N, Venkataraman W, Kerby JT. Gelada feeding ecology in an intact ecosystem at Guassa, Ethiopia: variability over time and implications for theropith and hominin dietary evolution. American Journal of Physical Anthropology. 2014;155:1-16.

Gebrehiwot T, van der Veen A. Assessing the evidence of climate variability in the northern part of Ethiopia. J Dev Agric Econ. 2013;5(3):104-19.

Gippoliti S. Theropithecus gelada distribution and variations related to taxonomy: history, challenges and implications for conservation. Primates. 2010;51:291-7.

Gippoliti S, Hunter C. Theropithecus gelada. The IUCN red list of threatened species: e.T21744A9316114; 2008.

Habtamu A, Subramanian C. Population size and structure of gelada baboon (Theropithecus gelada-Ruppel, 1835) in Simien Mountains National Park, Ethiopia. Glob J Biol Agri Health Scie. 2013;2:102-6.

Iwamoto T, Dunbar RIM. Thermoregulation, habitat quality and behavioural ecology of gelada baboons. J Anim Ecol. 1983;52:357-66.

Jablonski NG. The phylogeny of Theropithecus. In: Jablonski NG, editor. Theropithecus: the rise and fall of a primate genus. Cambridge.: Cambridge University Press; 1993. p. 209-24.

Kassahun A, Afework B. Population estimate, group size and age structure of the gelada baboon (Theropithecus Gelada) around Debre-Libanos, Northwest Shewa Zone, Ethiopia. Global Journal of Science Frontier Research. 2017; 17(1):27-33.

Kassahun A, Afework B, Addisu M. Daily activity, feeding ecology and habitat association of Gelada baboon (Theropithecus gelada) around Debre-Libanos, Northwest Shewa Zone, Ethiopia. International Journal of Biodiversity and Conservation. 2017:9(6):232-8. 
Kelil A, Addisu M, Afework B, Fashing PJ. Diet and activity patterns of Arsi geladas in low-elevation disturbed habitat south of the Rift Valley at Indetu. Ethiopia. Primates. 2018;59:153-61.

Kingdon J. The Kingdon Field Guide to African Mammals. San Diego: Academic Press, Harcourt Brace and Company, Publishers; 1997. p. 464.

Mori A, Belay G. The distribution of baboon species and a new population of gelada baboons along the Wabi-Shebeli River, Ethiopia. Primates. 1990;1:495-508.

Mori A, Iwamoto T, Bekele A. Sociological and demographic characteristics of a recently found Arsi gelada population in Ethiopia. Primates. 1999;40:365-81.

Norton-Griffith M. Counting Animals. Nairobi, Kenya: Africa Wildlife Leadership; 1978.

Oates JF. The social life of a black and white colobus monkey, Colobus guereza. Z Tierp Sychol. 1977:45:1-60.

Radek F, Ladislav M, Daria B, Gustav C, Hošek M, Michaela P. The daily pattern of main activities in the gelada baboon (Theropithecus gelada). Acta Univ Agri Silvi Mend Brun. 2014;62:89-6.

Sicotte P, Macintosh AJ. Inter-group encounters and male incursions in Colobus vellerosus in central Ghana. Behaviour. 2004;141:533-54.

Sutherland WJ. Ecological census techniques, a hand book. Cambridge: Cambridge University Press; 1996.

Teklay G, Zeyede T. Human-wildlife conflicts in and around Choffa forest, Hawzien Woreda, Eastern Tigray, Northern Ethiopia: implication for conservation and conflict resolution. Int J Sci Res. 2017;6(3):1763-71.

Wallace RB. Seasonal variations in blackfaced black spider monkey (Ateleschamek) habitat use and ranging behavior in a Southern Amazonian Tropical Forest Am J Primatol. 2006;68:313-32.

Yalden DW, Largen MJ. The endemic mammals of Ethiopia. Mammal Rev. 1992; 22:115-50.

Zewdu K, Gurja B, Afewerk B. Population size, group composition and behavioral ecology of geladas and Huan-gelada conflict in Wonchit Vally, Ethiopia. Pakistan J Biol Sci. 2013;16(21):1248-59.

Zinner D, Atickem A, Beehner JC, Bekele A, Bergman TJ, Burke R, Dolotovskaya S, Fashing PJ, Gippoliti S, Knauf S, Knauf Y, Mekonnen A, Moges A, Nguyen N, Stenseth NC, Roos C. Phylogeography, mitochondrial DNA diversity, and demographic history of geladas (Theropithecus gelada). PLOS ONE. 2018;13(8):1-8.

\section{Publisher's Note}

Springer Nature remains neutral with regard to jurisdictional claims in published maps and institutional affiliations.

Ready to submit your research? Choose BMC and benefit from:

- fast, convenient online submission

- thorough peer review by experienced researchers in your field

- rapid publication on acceptance

- support for research data, including large and complex data types

- gold Open Access which fosters wider collaboration and increased citations

- maximum visibility for your research: over $100 \mathrm{M}$ website views per year

At $\mathrm{BMC}$, research is always in progress.

Learn more biomedcentral.com/submissions 